\title{
Results of the Fontan operation with no early mortality in 248 consecutive patients
}

\author{
Edward Malec ${ }^{1}$, Christoph Schmidt ${ }^{2}$, Anja Lehner ${ }^{3}$, Katarzyna Januszewska ${ }^{1}$ \\ 'Department of Cardiothoracic Surgery, Division of Paediatric Cardiac Surgery, University Hospital Münster, Germany \\ ${ }^{2}$ Department of Anaesthesiology, University Hospital Münster, Germany \\ ${ }^{3}$ Department of Paediatric Cardiology, University Hospital Munich (LMU), Germany
}

\begin{abstract}
Background: The Fontan operation has undergone several modifications and today is the primary way to treat a broad spectrum of congenital heart defects.

Aim: The purpose of this study is to present the results of treatment of children with a single ventricle operated by the same surgical team and managed according to a uniform strategy.

Methods: In the years 2007-2015, in 248 children aged $3.7 \pm 2.6$ years and weighing $14.6 \pm 6.1 \mathrm{~kg}$ with a single ventricle, Fontan surgery was performed. In $56(22.6 \%)$ children surgery was based on the creation of an intra-atrial lateral tunnel, and in 192 (77.4\%) patients extracardiac modification was performed. In most patients, the operation was carried out with the normothermic cardiopulmonary bypass, on a "beating heart" without aortic cross-clamp. The average cardiopulmonary bypass time was $53.9 \pm 23.9 \mathrm{~min}$. The most common indication for surgery was hypoplastic left heart syndrome (53.6\%). All patients with a single ventricle referred to our hospital for the Fontan procedure were enrolled into the surgery programme. Results: All patients survived the operation and were discharged home. Thirty-six (14.5\%) patients were extubated in the operating room, in other patients the mean duration of the mechanical ventilation was $9.7 \pm 16.1 \mathrm{~h}$ (median $7 \mathrm{~h}$ ). The average time of hospitalisation in the whole study group was $17.5 \pm 18.5$ days (median 15 days). After surgery, in four children transient seizures occurred, and three patients had an ischaemic stroke.

Conclusions: Developing and obeying a fixed perioperative protocol is crucial for low mortality and small number of complications after Fontan operation.
\end{abstract}

Key words: single ventricle, Fontan operation

Kardiol Pol 2017; 75, 3: 255-260

\section{INTRODUCTION}

The Fontan operation, since its introduction in 1968, has undergone several modifications and today is the primary way to treat a broad spectrum of congenital heart defects, where there is only one fully developed ventricle [1]. The aim of the surgery is to separate the systemic circulation from the pulmonary circulation, achieving normal oxygen saturation and unloading the systemic ventricle.

A more thorough understanding of post-Fontan physiology, modifications in surgical technique, and advances in perioperative care have led to improved outcomes. Over the past 20 years the survival rate after surgery increased from $75 \%$ to over $90 \%$ [2-4].
Perioperative failures are mainly related to ventricular dysfunction, thromboembolic complications, and multi-organ failure $[5,6]$. This is due to ventricular hypertrophy, right ventricular (RV) morphology of a single ventricle, regurgitation of atrioventricular valves, hypoplasia of the pulmonary arteries, arrhythmias, or problems related to the anatomy (e.g. heterotaxy syndrome) $[7,8]$. The duration of cardiopulmonary bypass time and aortic cross-clamp can also affect the post-operative mortality $[2,5]$.

The strategy used in our centre focuses on the proper preparation of patients for Fontan surgery in terms of anatomy and haemodynamics, via initial palliative surgeries and interventional procedures, according to a plan drawn up at the time 
of diagnosis in the neonatal period. Our experience shows that the shortening of cardiopulmonary bypass time, elimination of hypothermia, elimination of aortic cross-clamp, achieving optimal cardiac output during post-operative period, avoiding damage to the phrenic nerves, and factors which may cause strokes have a significant impact on the early and late outcome. We believe that developing a constant perioperative, anaesthetic, and surgical strategy, as well as post-operative treatment, have crucial importance in reducing mortality and complications after Fontan surgery.

The aim of this study is to analyse our experience in the treatment of complex congenital heart malformations with the Fontan procedure, including mortality, post-operative course, and early and late complications.

\section{METHODS}

In the years 2007-2015 in two centres 248 Fontan operations were performed in a consecutive group of children with a single ventricle. All surgeries were carried out by one team of surgeons (EM, KJ). In 56 (22.6\%) patients an intracardiac lateral tunnel (LT) directing the flow from the inferior vena cava into the pulmonary artery was created, and in 192 (77.4\%) extracardiac modification of Fontan operation was performed (EC). Intracardiac operation was performed in almost all patients who had previously undergone the hemi-Fontan procedure, and extracardiac modification was used in all children after bidirectional Glenn anastomosis. In 2007, the hemi-Fontan procedure was replaced by the bidirectional Glenn operation. All patients referred to our hospital for Fontan procedure were admitted and operated on.

The mean age of children at the time of surgery was $3.7 \pm 2.6$ years, and the mean body weight was $14.6 \pm 6.1 \mathrm{~kg}$. The most common indication for Fontan operation was hypoplastic left heart syndrome (HLHS) in 133 (53.6\%) children, variants of HLHS in 28 (11.3\%), hypoplastic right heart syndrome (HRHS) in 31 (12.5\%), HRHS variants in $21(8.5 \%)$, and in 20 (8.1\%) patients double inlet left ventricle (LV). Variants of HLHS include defects such as: unbalanced atrioventricular canal with hypoplastic LV or double outlet RV with hypoplastic LV. Variants of HRHS were defined as an unbalanced atrioventricular canal with hypoplastic RV or transposition of the great arteries with tricuspid atresia. During the preoperative echocardiographic examination of the morphology of the single ventricle, the morphology of the RV was observed in 161 (64.9\%) children, and the LV in $72(29.0 \%)$. In other patients, ventricle morphology was impossible to determine or it was a common ventricle. All patients immediately before surgery and before discharge home had an electrocardiographic examination. Cardiac catheterisation was carried out on average one day before surgery (range: 0-5 days before operation).

The amount and duration of effusions to the pleural and peritoneal cavities in the postoperative course was analysed.
Table 1. Type of initial procedure

\begin{tabular}{|lc|} 
Type of surgery & N (\%) \\
\hline Norwood operation with RV-PA shunt & $153(61.7 \%)$ \\
Norwood operation with Blalock-Taussig shunt & $15(6.0 \%)$ \\
Aorto-pulmonary shunt & $33(13.3 \%)$ \\
Banding of the PA & $20(8.1 \%)$ \\
Aortic arch repair with PA banding & $9(3.6 \%)$ \\
Aortic arch/coarctation repair & $4(1.6 \%)$ \\
\hline
\end{tabular}

PA — pulmonary artery; RV — right ventricle

Drains were removed if the amount of fluid was less than $3 \mathrm{~mL} / \mathrm{kg}$ body weight per day. Effusions lasting longer than 10 days from the surgery were defined as chronic.

In the neonatal period and early infancy in nearly 95\% of patients the initial surgery was carried out (Table 1). Only $14(5.6 \%)$ children did not need in the first months of life any surgery that prepares the circulatory system to passive pulmonary blood flow, due to the balanced systemic and pulmonary circulations (no symptoms of congestive heart failure and sufficient oxygenation of the blood).

In all patients, as an intermediate stage of the treatment, anastomosis of the superior vena cava to the pulmonary artery system was performed: in $58(23.4 \%)$ it was a hemi-Fontan procedure, and in 190 (76.6\%) it was bidirectional Glenn anastomosis. Bilateral bidirectional Glenn anastomosis was required by $21 / 190(11.1 \%)$ children, due to the presence of the additional vena cava superior without an innominate vein. In three children during the hemi-Fontan operation, bidirectional Glenn anastomosis on the left side was performed.

In 56 (22.6\%) patients an intra-atrial LT was made with cardiopulmonary bypass (bicaval and aortic cannulation), moderate hypothermia, after aortic cross-clamp and cardioplegic solution administration. Once resternotomy was performed, dissection was limited to a portion of the ascending aorta and venae cavae. The wall of the tunnel within the atrium was created using a patch made from prosthetic vascular graft (polytetrafluoroethylene [PTFE]) with a diameter of $10 \mathrm{~mm}$. In almost all children a small hole was made in the patch (fenestration) having a diameter of $3 \mathrm{~mm}$.

Extracardiac anastomosis of the inferior vena cava with the system of pulmonary artery (EC) was created in 192 (77.4\%) children. The surgery was performed with cardiopulmonary bypass, bicaval and aortic cannulation, normothermia, without cardioplegic cardiac arrest (on a "beating heart"). The inferior caval vein was divided from the right atrium and then anastomosed with an PTFE graft (18 $\mathrm{mm}$ or $20 \mathrm{~mm}$ in diameter). Opposite to the Glenn anastomosis, the right pulmonary artery was longitudinally opened and associated with the second end of the ePTFE conduit "side-to-end". In seven (3.6\%) patients 
Table 2. Haemodynamic parameters before Fontan operation

\begin{tabular}{|lc|}
\hline Haemodynamic parameter & Mean \pm SD \\
\hline Mean pulmonary artery pressure $[\mathrm{mm} \mathrm{Hg}]$ & $11.1 \pm 2.5$ \\
Mean right atrial pressure $[\mathrm{mm} \mathrm{Hg}]$ & $6.6 \pm 2.2$ \\
Systemic-to-pulmonary flow ratio & $0.74 \pm 0.3$ \\
Oxygen saturation in the aorta [\%] & $83.7 \pm 5.5$ \\
Oxygen saturation in the inferior vena cava [\%] & $65.1 \pm 7.6$ \\
Ventricular end diastolic pressure [mm Hg] & $10.5 \pm 3.5$ \\
\hline
\end{tabular}

SD - standard deviation

with absent inferior vena cava, the anastomosis was performed between the hepatic veins and the pulmonary artery, using a vascular graft with a diameter of 14-16 mm (always as a separate stage procedure after so-called Kawashima operation). In most patients, an extracardiac conduit was placed on the right side, and in five (2.6\%) patients with a situs inversus or a heterotaxy syndrome, on the left side.

Only in 11/192 (5.7\%) children during the extracardiac Fontan procedure was the heart stopped in order to repair of atrioventricular valves (seven children), to enlarge the interatrial communication (two children), or to create a connection between the pulmonary artery and the ascending aorta (Damus-Kaye-Stansel operation) in two children.

Fenestration was created in 2/192 (1.0\%) patients with extracardiac modification and in 54/56 (96.4\%) patients with intracardiac lateral tunnel.

In all patients during cardiopulmonary bypass, conventional ultrafiltration was used.

After the surgery, most patients had continuous infusion of milrinone $(0.25-0.75 \mu \mathrm{g} / \mathrm{kg} / \mathrm{min})$ and dopamine (3-5 $\mu \mathrm{g} / \mathrm{kg} / \mathrm{min}$ ). The anticoagulation was started on the day of operation with unfractionated heparin (goal PTT: 50-60 s). In the first 3-5 days after operation in children with intracardiac LT aspirin was started $(2-3 \mathrm{mg} / \mathrm{kg})$, and in the children with extracardiac conduit warfarin (goal INR: 2-3) for six months, and subsequently only aspirin.

\section{Statistical analysis}

The data are represented as mean \pm standard deviation or median with range. The statistical analysis was carried out by means of descriptive statistics and Mann-Whitney's test or Student's t-test for continuous variables. Differences were considered statistically significant at the $p$ value of $<0.05$.

\section{RESULTS}

All patients survived the operation and were discharged home.

The results of preoperative haemodynamic examination are presented in Table 2. At the time of cardiac catheterisation aortopulmonary collaterals were closed if needed and, depending on indications, balloon angioplasty of the pulmonary arteries with or without stent implantation was performed.
Aortopulmonary collaterals were closed in 41 (16.5\%) patients. Balloon dilatation of the left pulmonary artery was required in $44(17.7 \%)$ patients, and in $23(9.3 \%)$ of these patients stents were applied. In 12 (4.8\%) children the right pulmonary artery was dilated; only three $(1.2 \%)$ required the application of a stent. The balloon angioplasty of the aortic coarctation during cardiac catheterisation was performed in $12(4.8 \%)$ patients.

The mean time of cardiopulmonary bypass during surgery was $53.9 \pm 23.9 \mathrm{~min}(23-207 \mathrm{~min})$ and was significantly shorter in children with extracardiac conduit (LT $61.0 \mathrm{~min}$ [32-207 min] vs. EC $41.5 \mathrm{~min}$ [23-174 $\mathrm{min}$ ]; $p=0.004)$. The average aortic cross-clamp time was $34.9 \pm 10.4 \mathrm{~min}$.

The average stay in the intensive care unit was $4.0 \pm 9.2$ days, and the time of mechanical ventilation was $9.7 \pm 16.1 \mathrm{~h}$ (median $7 \mathrm{~h}$ ). Immediately after the surgery (in the operating room) 36 (14.5\%) patients were extubated. Since January 1, 2015 our centre has introduced the strategy of early extubation of the majority of patients after surgery of congenital heart defects in the operating room.

The mean duration of the hospital stay was $17.5 \pm 18.5$ days (median 15 days). Patients who underwent fenestrated Fontan procedure tended to have fewer effusions (with fenestration: $10.79 \pm 5.3 \mathrm{~mL} / \mathrm{kg} /$ day vs. without a fenestration: $12.98 \pm 6.8 \mathrm{~mL} / \mathrm{kg} /$ day; $\mathrm{p}=0.05)$. In 37 (14.9\%) children prolonged effusions to pleural cavities were observed ( $>10$ days): in $7 / 56(12.5 \%)$ patients with fenestration and in 30/192 (15.6\%) without fenestration.

Reoperation due to postoperative bleeding was required in two $(0.8 \%)$ patients. Generalised transient seizures in the early postoperative course occurred in four $(1.6 \%)$ children, and three $(1.2 \%)$ patients had ischaemic stroke with hemiplegic paralysis. In all patients who developed seizures, magnetic resonance of the central nervous system was performed and no structural changes were found.

In the immediate postoperative period the majority of the patients $(61.7 \%)$ demonstrated sinus rhythm. Temporary pacing (mostly in AAI modus) was required in 53 (21.4\%) children. The most common indication for temporary pacing was the junctional rhythm or atrial rhythm. Upon discharge from hospital sinus rhythm was present in 181 (72.9\%) children.

The mean follow-up was $4.3 \pm 2.1$ years (range, 8.8 years to four months) and was complete in $94.8 \%$ (13 patients were lost from follow-up). In the long term follow-up four (1.6\%) children died. One child died suddenly five months after the surgery, due to unclear reasons; two children died three months and four years after the Fontan surgery (EC) because of the ventricular dysfunction; and one child died after one year due to the failure of Fontan circulation.

Protein loosing enteropathy (PLE) developed in seven $(2.8 \%)$ children. Plastic bronchitis was diagnosed in three $(1.2 \%)$ children after extracardiac modification. In four patients with PLE extracardiac modification of Fontan surgery was performed, and three patients had an intracardiac one. 
The treatment of PLE included pacemaker implantation in two patients due to sinus node dysfunction and operative enlargement of the interatrial communication. All patients who developed PLE or plastic bronchitis were re-catheterised. In three children a fenestration was performed during cardiac catheterisation. Additionally, two of them underwent balloon angioplasty of the left pulmonary artery, achieving remission. In the 1.5 years after the surgery one patient had an ischaemic stroke. Embolic material came from the stump of the pulmonary artery. During reoperation the organised thrombus was removed and the stump of the pulmonary artery and the remnants of the pulmonary valve were directly closed. One patient, 18 months after the surgery, had a recurrent bleeding from the respiratory tract, which stopped after the closure of aortopulmonary of collaterals during cardiac catheterisation and discontinuation of aspirin.

\section{DISCUSSION}

The perspectives for children with single ventricle have improved dramatically over the past two decades. Today, children who are managed carefully in infancy, to optimise their anatomy and physiology, are good candidates for Fontan procedure and have a very high probability of having good quality of life with minimal restrictions. According to the current strategy, children with single ventricle require multi-stage treatment. Fontan surgery is only a part of that plan. The time of Fontan operation should be planned, and should not be the result of increasing cyanosis or worsening of the clinical condition of a child. Early implementation of Fontan physiology is of crucial importance for the future of a patient with a single ventricle. It should be done before the development of collateral circulation (associated with severe cyanosis) and before the development of regurgitation of atrioventricular valves, caused on the one hand by volume overload of the ventricle and on the other by its dysfunction (consequence of the myocardial fibrosis caused by chronic hypoxia) [9-17].

With the increasing interval between the hemi-Fontan or bidirectional Glenn operation and Fontan procedure, the risk of blood coagulation disorders increases, the common atrial pressure increases and as well as end diastolic pressure in the ventricle. These factors are considered clearly as increasing the risk of Fontan operation [12]. According to our observations the age of about two years is the best time to perform a Fontan procedure.

It is extremely important to carefully prepare the patient for Fontan operation.

In our centre, cardiac catheterisation is performed immediately before the planned surgery. The aim of the catheterisation is to obtain current haemodynamic and anatomic data, to close significant aortopulmonary collaterals, and, depending on indications, to perform balloon angioplasty of the stenotic pulmonary arteries or the re-coarctation of the aorta. The presence of major aortopulmonary collateral arter- ies increases the time of post-surgical effusions and hospitalisation [15] due to ventricular volume overloading. Our strategy is based on the elimination of all additional sources of blood supply to the pulmonary circulation (systemic-to-pulmonary shunts, vessels of collateral circulation, open main pulmonary artery) during the hemi-Fontan/bidirectional Glenn operation and additionally in case of their presence during the cardiac catheterisation immediately before Fontan surgery or during it.

Many authors believe that hypoplastic left heart syndrome is an increased risk of mortality or complications after Fontan procedure $[5,18,19]$. Our observations do not confirm these reports. Over $50 \%$ of our patients who underwent Fontan operation were children with HLHS.

Currently, there are two techniques of Fontan procedure: intra-atrial LT [20-22] and extracardiac conduit [23, 24]. Intra-atrial tunnel is associated with an increased risk of postoperative atrial rhythm disorders due to long suture lines within the atrium. On the other hand, since the atrium wall is part of the tunnel, there is the potential of enlarging the tunnel with the patient's growth. Creating the tunnel, however, requires aortic cross-clamp and opening of the atrium. Extracardiac conduit does not require aortic cross-clamp, reduces the risk of postoperative arrhythmia, eliminates artificial materials in the systemic atrium, and is characterised by better flow dynamics in comparison to intra-atrial tunnel [24]. Changing of the technique of Fontan operation from intra-atrial to extracardiac in the population of our patients helped to eliminate or significantly reduce aortic cross-clamp time and cardiopulmonary bypass time.

Shorter cardiopulmonary bypass time and elimination of cardioplegic cardiac arrest may reduce the adverse impact of these factors on the compliance of the single ventricle and pulmonary vascular resistance, affecting significantly the early postoperative course and late results of Fontan operation $[2,5,23]$. Extracardiac conduit can also be constructed without the use of cardiopulmonary bypass [23].

The extracardiac conduit has no growth potential and may increase the risk of thromboembolic complications. We did not observe any such complications among our patients.

After changing the technique from intracardiac to extracardiac we abandoned the routine fenestration and we did not see any major consequences of that fact. Currently we perform fenestration only in patients with ventricular dysfunction or significant regurgitation of atrioventricular valves — factors identified as increasing the risk of Fontan operation. Low McGoon Index is not an indication for fenestration in our centre (the analysis of our experience regarding the influence of the pulmonary artery size on the early results has been published already [9].

Precise and limited intraoperative dissection significantly reduces the risk of the damage of the phrenic nerves and postoperative bleeding. Paralysis of the diaphragm caused serious consequences for children with Fontan circulation [25]. 
All patients during cardiopulmonary bypass underwent a conventional ultrafiltration. Ultrafiltration contributes to a reduction in the extracellular fluid and inflammatory mediators [26]. As a routine after Fontan surgery we use milrinone and dopamine in order to prevent low cardiac output.

Limitations of the study were the retrospective nature of the analysis and the relatively short time of follow-up. Our group of patients were from many different countries, and this was the reason for the lack of $100 \%$ complete follow-up.

\section{CONCLUSIONS}

Thanks to developing a constant surgical technique and postoperative management, we have achieved $100 \%$ early survival and a relatively small number of complications.

\section{Conflict of interest: none declared}

\section{References}

1. Fontan F, Baudet E. Surgical repair of tricuspid atresia. Thorax. 1971; 26(3): 240-248, indexed in Pubmed: 5089489.

2. Mayer JE, Bridges ND, Lock JE, et al. Factors associated with marked reduction in mortality for Fontan operations in patients with single ventricle. J Thorac Cardiovasc Surg. 1992; 103(3): 444-452, indexed in Pubmed: 1545543.

3. Gentles TL, Mayer JE, Gauvreau K, et al. Fontan operation in five hundred consecutive patients: factors influencing early and late outcome. J Thorac Cardiovasc Surg. 1997; 114(3): 376-391, indexed in Pubmed: 9305190.

4. Jacobs ML, Pelletier GJ, Pourmoghadam KK, et al. Protocols associated with no mortality in 100 consecutive Fontan procedures. Eur J Cardiothorac Surg. 2008; 33(4): 626-632, doi: 10.1016/j.ejcts.2007.12.032, indexed in Pubmed: 18243008 .

5. Gentles TL, Gauvreau K, Mayer JE, et al. Functional outcome after the Fontan operation: factors influencing late morbidity. J Thorac Cardiovasc Surg. 1997; 114(3): 392-403; discussion 404, indexed in Pubmed: 9305191.

6. Van Arsdell GS, McCrindle BW, Einarson KD, et al. Interventions associated with minimal fontan mortality. Ann Thorac Surg. 2000; 70(2): 568-574, indexed in Pubmed: 10969682.

7. Julsrud PR, Weigel TJ, Van Son JA, et al. Influence of ventricular morphology on outcome after the Fontan procedure. Am J Cardiol. 2000; 86(3): 319-323, indexed in Pubmed: 10922441.

8. Yoshimura N, Yamaguchi M, Oshima Y, et al. Risk factors influencing early and late mortality after total cavopulmonary connection. Eur J Cardiothorac Surg. 2001; 20(3): 598-602, indexed in Pubmed: 11509285.

9. Lehner A, Schuh A, Herrmann FEM, et al. Influence of pulmonary artery size on early outcome after the Fontan operation. Ann Thorac Surg. 2014; 97(4): 1387-1393, doi: 10.1016/j.athoracsur.2013.11.068, indexed in Pubmed: 24529483.

10. Ota N, Fujimoto Y, Murata M, et al. Impact of postoperative hemodynamics in patients with functional single ventricle undergoing Fontan completion before weighing $10 \mathrm{~kg}$. Ann Thorac Surg. 2012; 94(5): 1570-1577, doi: 10.1016/j.athoracsur.2012.06.022, indexed in Pubmed: 22884600.

11. Milanesi O, Stellin G, Colan S, et al. Systolic and diastolic performance late after the Fontan procedure for a single ventricle and comparison of those undergoing operation at $<12$ months of age and at >12 months of age. Am J Cardiol. 2002; 89(3): 276-280, doi: 10.1016/s0002-9149(01)02227-5.
12. Odegard KC, McGowan FX, Zurakowski D, et al. Coagulation factor abnormalities in patients with single-ventricle physiology immediately prior to the Fontan procedure. Ann Thorac Surg. 2002; 73(6): 1770-1777, indexed in Pubmed: 12078768.

13. Sathanandam S, Polimenakos AC, Blair C, et al. Hypoplastic left heart syndrome: feasibility study for patients undergoing completion fontan at or prior to two years of age. Ann Thorac Surg. 2010; 90(3): 821-8; discussion 828, doi: 10.1016/j.athoracsur.2010.04.079, indexed in Pubmed: 20732502.

14. Petrossian Ed, Reddy VM, McElhinney DB, et al. Early results of the extracardiac conduit Fontan operation. J Thorac Cardiovasc Surg. 1999; 117(4): 688-696, doi: 10.1016/S0022-5223(99)70288-6, indexed in Pubmed: 10096963.

15. Spicer RL, Uzark KC, Moore JW, et al. Aortopulmonary collateral vessels and prolonged pleural effusions after modified Fontan procedures. Am Heart J. 1996; 131(6): 1164-1168, indexed in Pubmed: 8644596.

16. Chowdhury UK, Airan B, Sharma R, et al. Univentricular repair in children under 2 years of age: early and midterm results. Heart Lung Circ. 2001; 10(1): 3-13, doi: 10.1046/j.1444-2892.2001.000 76.x, indexed in Pubmed: 16352019.

17. Ikai A, Fujimoto Y, Hirose K, et al. Feasibility of the extracardiac conduit Fontan procedure in patients weighing less than $10 \mathrm{ki}-$ lograms. J Thorac Cardiovasc Surg. 2008; 135(5): 1145-1152, doi: 10.1016/j.jtcvs.2007.12.013, indexed in Pubmed: 18455596.

18. Knott-Craig CJ, Danielson GK, Schaff HV, et al. The modified Fontan operation. An analysis of risk factors for early postoperative death or takedown in 702 consecutive patients from one institution. J Thorac Cardiovasc Surg. 1995; 109(6): 1237-1243, doi: 10.1016/S0022-5223(95)70208-3, indexed in Pubmed: 7776688.

19. Caspi J, Coles JG, Rabinovich M, et al. Morphological findings contributing to a failed Fontan procedure. Twelve-year experience. Circulation. 1990; 82(5 Suppl): IV177-IV182, indexed in Pubmed: 1699687.

20. Gaynor JW, Bridges ND, Cohen MI, et al. Predictors of outcome after the Fontan operation: is hypoplastic left heart syndrome still a risk factor? J Thorac Cardiovasc Surg. 2002; 123(2): 237-245, indexed in Pubmed: 11828282.

21. Kaulitz R, Ziemer G, Luhmer I, et al. Modified Fontan operation in functionally univentricular hearts: preoperative risk factors and intermediate results. J Thorac Cardiovasc Surg. 1996; 112(3): 658-664, doi: 10.1016/S0022-5223(96)70049-1, indexed in Pubmed: 8800153.

22. Mosca RS, Kulik TJ, Goldberg CS, et al. Early results of the fontan procedure in one hundred consecutive patients with hypoplastic left heart syndrome. J Thorac Cardiovasc Surg. 2000; 119(6): 1110-1118, doi: 10.1067/mtc.2000.106656, indexed in Pubmed: 10838526

23. Petrossian E, Thompson LD, Hanley FL. Extracardiac conduit variation of the Fontan procedure. Adv Card Surg. 2000; 12: 175-198, indexed in Pubmed: 10949650.

24. Marcelletti C, Corno A, Giannico S, et al. Inferior vena cava-pulmonary artery extracardiac conduit. A new form of right heart bypass. J Thorac Cardiovasc Surg. 1990; 100(2): 228-232, indexed in Pubmed: 2143549.

25. Ovroutski S, Alexi-Meskishvili V, Stiller B, et al. Paralysis of the phrenic nerve as a risk factor for suboptimal Fontan hemodynamics. Eur J Cardiothorac Surg. 2005; 27(4): 561-565, doi: 10.1016/j. ejcts.2004.12.044, indexed in Pubmed: 15784351.

26. Koutlas TC, Gaynor JW, Nicolson SC, et al. Modified ultrafiltration reduces postoperative morbidity after cavopulmonary connection. Ann Thorac Surg. 1997; 64(1): 37-43, indexed in Pubmed: 9236332.

Cite this article as: Malec E, Schmidt Ch, Lehner A, Januszewska K. Results of the Fontan operation with no early mortality in 248 consecutive patients. Kardiol Pol. 2017; 75(3): 255-260, doi: 10.5603/KP.a2016.0170. 


\title{
Wyniki operacji Fontana u 248 pacjentów
}

\author{
Edward Malec ${ }^{1}$, Christoph Schmidt ${ }^{2}$, Anja Lehner ${ }^{3}$, Katarzyna Januszewska ${ }^{1}$ \\ 1'Department of Cardiothoracic Surgery, Division of Paediatric Cardiac Surgery, University Hospital Münster, Niemcy \\ ${ }^{2}$ Department of Anaesthesiology, University Hospital Münster, Niemcy \\ ${ }^{3}$ Department of Paediatric Cardiology, University Hospital Munich (LMU), Niemcy
}

\section{Streszczenie}

Wstęp: Operacja Fontana przeszła wiele modyfikacji i obecnie jest metodą z wyboru leczenia szerokiego spektrum wad serca o typie pojedynczej komory.

Cel: Celem pracy jest przedstawienie wyników leczenia dzieci z pojedynczą komorą serca, leczonych przez ten sam zespół wg jednolitej strategii postępowania.

Metody: W latach 2007-2015 u 248 dzieci w średnim wieku 3,7 $\pm 2,6$ roku i z masą ciała 14,6 \pm 6,1 kg z pojedynczą komorą przeprowadzo operację Fontana. U 56 (22,6\%) dzieci operacja polegała na wytworzeniu wewnątrzprzedsionkowego tunelu, a u 192 (77,4\%) pacjentów wykonano zewnątrzsercową modyfikację. U większości chorych operację przeprowadzono w krążeniu pozaustrojowym, normotermii, na „bijącym sercu“, bez klemowania aorty. Średni czas krążenia pozaustrojowego wynosił 53,9 \pm 23,9 min. Najczęstszym wskazaniem do operacji był zespół niedorozwoju lewego serca (53,6\%). Wszyscy pacjenci z pojedynczą komorą skierowani do naszego ośrodka w celu przeprowadzenia operacji Fontana zostali zakwalifikowani do operacji.

Wyniki: Wszyscy pacjenci przeżyli operację i zostali wypisani do domu. 36 (14,5\%) chorych ekstubowano w sali operacyjnej, u pozostałych średni czas mechanicznej wentylacji wynosił 9,7 $\pm 16,1 \mathrm{~h}$ (mediana $7 \mathrm{~h}$ ), a średni czas hospitalizacji 17,5 \pm 18,5 dnia (mediana 15 dni). Po operacji u 4 dzieci wystąpiły przejściowe drgawki, a u 3 doszło do niedokrwiennego udaru mózgu.

Wnioski: Wypracowanie i przestrzeganie stałego protokołu okołooperacyjnego umożliwia przeprowadzenie operacji Fontana z niską śmiertelnością i niewielką liczbą powikłań.

Słowa kluczowe: pojedyncza komora, operacja Fontana

Kardiol Pol 2017; 75, 3: 255-260 